\title{
THE ATTITUDE OF THE RAILROAD BROTHERHOODS TOWARD HOURS AND WAGES
}

\author{
By A. B. Garretson, \\ President, Order of Railway Conductors of America.
}

To understand the attitude of the brotherhoods toward the question of the shortening of the hours in connection with the wage rate in the late eight-hour movement it is necessary to have some knowledge of the conditions under which train and enginemen serve.

When the brotherhoods came into existence in the militant sense there were no limitations whatever upon the hours of service. Even the twenty-four hours in the calendar day were not a limit. The time to complete a trip, even though it might require two or three times twenty-four hours, was the requirement and no overtime was paid-only the trip allowance being made, whatever it might be. The men, through their organizations, first succeeded in establishing the twelve-hour day, then the ten, but during all those years the greater part of their energy was expended on the question of increasing the wage, while at the same time striving to limit the excessive use of men even where overtime was paid. Every agreement between these organizations and their employing railways used to provide that when a man had been used for a certain period-presumably sixteen hours-he should be entitled to rest, no matter where he might be, but this rule was shamelessly violated and as an outgrowth thereof effort was made by legislative enactment, and what is known as the "Hours of Service Act," fining the employers for permitting men to work a longer period than sixteen continuous hours, was enacted, but under the guise of casualties thousands of men every month, as shown by the reports of the Interstate Commerce Commission, are working periods ranging from sixteen to sixty-five hours or upwards, and experience has shown that the enactment of that sixteen-hour law operated to establish a sixteen-hour day instead of a ten-hour day, as was in force and effect, each hour thereof being paid at the pro rata rate under the present overtime regulations.

The men therefore determined to concentrate the energies of 
the four brotherhoods upon the effort to do away with such excessive hours and they formulated the demand for the eight-hour day, accompanied by the demand for time and one-half time for overtime as a purely punitive measure in the hope of making it uneconomic to use men for the excessive periods which they were being used under the going arrangement, which prompted the company to use the men up to the sixteenth hour for the same rate of pay that was paid to them for the first or any one of the succeeding ten hours.

Had the real purpose of the men been only an increase in wages the punitive overtime would never have been demanded because the true incentive to work the men long hours lies in the economic feature thereof, and the way to have produced an increase in earnings would have been to have demanded the eight-hour day with overtime on the pro rata basis, as has formerly obtained. The one feature of their demand which the men most strongly insisted upon was the punitive overtime because they realized that no other agency would decrease the hours required of them to the same extent. And they further realized from practical knowledge of operation that overtime in train service is, all statements to the contrary notwithstanding, largely a controllable factor which will be controlled whenever the profit is taken from it.

The following statement by President Lovett of the Harriman Lines made before the Senate Committee on Interstate Commerce Commission in the hearing on the eight-hour bill brought out the real attitude of the railways:

We will run the railroads just as we do now and pay the overtime. That is the cheapest way out. Of course, we will do it the cheapest way we can. . . . . That is the deliberate judgment of these men (railroad operating officers) as being the most economical.

In other words, the railroad companies were desirous of working men for the sixteen-hour day if it brought economic gain. Not the slightest trace of humanism appeared in their attitudejust the reiteration of the ages old position-that life, comfort, safety and happiness must all be relegated to the rear rank when profits loom large in the foreground.

The real questions were: Should men entrusted with the safety of train movement be required to work hours that make "Safety First" an empty phrase? Or should they be permitted to cease labor as soon after the lapse of a period which every tribunal, 
social or hygienic in its character, has declared to be as long as men should be allowed or required to work, in view of the character of their service? Or, is the contention of the railway officials to be upheld that men should be worked as long as it is economic for the employer to work them?

The position of the railway employes was that they would shorten the hours with a probable diminution of earnings in preference to taking an increase in the wage scale, leaving the present time requirements made upon them in effect. 